University of East Africa Social Science Conference. The conference on oral history was attended by thirteen historians working mainly from oral sources, including six Tanzanians, two archaeologists, and two anthropologists. The participants included Mr. S. Feierman (Shambala), Mr. C. F. Holmes (Sukuma), Professor A. Jacobs (Masai), Miss M. Jellicoe (Nyaturu), Dr. I. Kimambo (Pare), and Dr. A. D. Roberts (W. Nyamwezi). There were also three research students who have recently begun field-work: Mr. M. M. Alidina (N.E. coast), Mr. P. Pender-Cudlip (Iramba), and Mr. A. C. Unomah (Nyamwezi of Unyanyembe). There are plans for research in Ujiji, Bagamoyo, and Ukerewe; but much valuable work could also be done in Usagara and Buha. Plans are now well advanced for a collaborative Early History of Tanzania, which will appear later this year from East African Publishing House, Nairobi and the Department of History at Dar es Salaam has produced the first two issues of Tanzania Zamani, a bulletin of current research on pre-colonial history. Records of Pare and Shambala traditions are to be made available for use in the Department's B.Litt. and M.A. courses, which begin this year; and recordings from the Nyamwezi and Sumbwa are being selected and edited for deposit at the college as the nucleus of an 'oral archive'.

(Communicated by Dr. Andrew Roberts)

\title{
Local Development in Sub-Saharan Africa
}

A CONFERENCE on this theme was held at the Foreign Service Institute of the Department of State, Washington D.C., on I 8 and I9 July 1967, under the chairmanship of Arnold Rivkin of the International Bank for Reconstruction and Development. It was sponsored by the Institute, the Africa Subcommittee of the Foreign Area Research Coordination Group (FAR), and the Agency for International Development, and was attended by fifty university and government African specialists. Papers were presented by Aristide Zolberg, (University of Chicago), and Martin Kilson (Harvard University Center for International Affairs). Case studies of local development in four African countries were discussed by David Brokensha (University of California at Santa Barbara); Nicholas Hopkins (New York University); William Foltz (Yale University), and Norman Miller (Michigan State University). Copies of the conference report may be obtained from the Office of External Research, Department of State, Washington, D.C. 20520.

\section{Netherlands Foundation for the Advancement of Tropical Research}

THE Foundation made the following grants for African studies in I966:

Africa Study Centre, Leiden: for agro-socio-economic research by a team of eight into the development of agriculture in the Rungwe District, Tanzania; for a comparative study of some separatist Bantu churches in Rhodesia, by Dr. M. L. Daneel.

University of Leiden: to Dr. J. Voorhoeve for socio-lingustic research in the Rungwe District, Tanzania.

\section{Field Research in the Comoro Islands}

Mr. and Mrs. Martin Ottenheimer of Tulane University, New Orleans, with a fellowship and grant from the NIMH, arrived in Moroni in October and have been making a preliminary ethnographic survey of the Comoro Islands. Investigation of the language and social organization will be followed by a study in depth of one particular community which will include an analysis of the socio-psychological factors related to the formal analysis of kinship terminology. The research will continue until February 1969. It is hoped that the final 